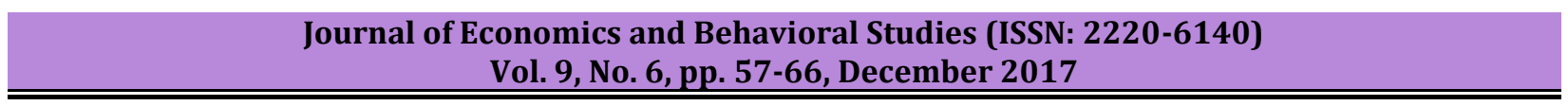

\title{
Formulation and validation of an Enabling Developmental Environment Scale (EDES) for local economic development (LED)
}

\author{
Daniel Francois Meyer, Elsabé Keyser \\ Faculty of Economics and Management Sciences, NWU, South Africa \\ danie.meyer@nwu.ac.za, elsabe.keyser@nwu.ac.za
}

\begin{abstract}
Local government is one of the main role players in local economic development (LED) and need to assist in the creation of an enabling developmental environment for local businesses to prosper. Partnerships are required between local government, businesses and communities for regions to develop, yet in many cases government at this level fails to create this developmental enabling environment. This research has as its focus on the formulation and validation of an Enabling Developmental Environment Scale (EDES). This scale will allow local government to be evaluated, assessed and compared regarding the creation of such a developmental environment. The pilot study involved152 participants from the Vaal Triangle region, South Africa. Reliability and construct validity of the instrument weretested by using the Cronbach's Alpha Coefficient and Varimax Factor Analysis. It is evident from the results that thescale is a valid and reliable tool for researchers to evaluate and assess the level of an enabling environment as created by local government in a specific region.
\end{abstract}

Keywords: Enabling environment, Local economic development, Enabling Developmental Environment Scale

\section{Introduction}

One of the core functions of local government is to ensure that an enabling and developmental environment exists within a local region for business to prosper and for the region to achieve economic development (Mountford, 2009). One of the main functions of local government in South Africa since the first democratic elections in 1994 is Local Economic Development (LED) in partnership with other stakeholders including businesses and communities (Cohen, 2010). LED together with the function of creation of an enabling environment, was formally included in the Constitution in 1996 (South Africa, 1996). Since then, Section 152 of the Constitution, transformed the roles and functions of local governments to be more developmental and added the functions of social and economic development. The Education and Training Unit (ETU) (2012) states that a developmental local government speaks of a local government that maximizes social and economic growth, providing infrastructural services and creating liveable residential areas offering community facilities. After the democratic elections in 1994, and since 1996, local government in South Africa has struggled to implement this function of social and economic development for local communities that have the right to an enabling environment for such development, including the business community (Meyer, 2014). According to Nel and Rogerson (2005), South Africa's post-apartheid development policy concentrates on developmental government with a focus on community development and the disadvantaged poor section of the population. Local government has been encouraged to intervene and play a leading role in job creation and the reduction of poverty. The main constraints in delivering results, however, are poor analysis and understanding of local economies, unsustainable community development projects, as well as the lack of capacity and resources.

The Constitution is supported by the Public Administration Management Act of 2014 (South Africa, 2014), which instructs all levels of government to formulate and implement legislation, policy initiatives and other actions to achieve social and economic development. Also in support of the Constitution, the White Paper on Local Government (South Africa, 1998) lists a number of specific objectives for local government in LED. The White Paper preserved into statutory obligations of the Local Government known as the Municipal Systems Act 32 of 2000. Municipalities in South Africa must be development oriented, reliant on strategic and integrative planning to indicate a long-term vision of municipalities (Humby, 2015, p. 205). These actions include the coordination of social and economic development, resource redistribution, effective basic service delivery, minimization regulations, formulation and implementation of favourable local procurement policies, partnerships development and the creation of economically and socially resilient communities (South Africa, 
1998). The role of local government, therefore, has been extended from just the provision of basic services to include LED initiatives and the coordination of the local economy. Since the function of local government regarding social and economic development is still not well implemented owing to a lack of measurement tools to assess performance, the purpose of this article is to test and validate a scale for the creation of an enabling environment as implemented by local government. The factors were developed into a scale which could be used to determine the level of success and to compare regions in the creation of an enabling environment. The scale is also validated as part of this paper.

\section{Literature Review}

Local businesses need to form partnerships with local government; in this process, the latter should attempt to create and sustain an enabling environment for businesses to prosper, which could benefit local communities (Travers, 2012). Christy, Mabaya, Wilson \& Mhlanga (2009) define an enabling developmental environment as a collection of related policies strategies, organisations and services that create a positive business environment where business activities are able to start, develop and prosper. An effective enabling environment has the potential to boost the competitiveness of a specific region or area (Konig, Da Silva, \& Mhlanga, 2013). According to Van Den Dool (2005), the private sector or local businesses comprise the “motor' for Local Economic Development (LED), but local government should create an enabling environment for businesses and local community organisations to be successful. According to Leigh and Blakely (2013), such an environment could be createdby means of processes to limit 'red tape', by providing infrastructure capacity, skills training, information provision and to ensure safety and security. The government could also assist in supporting existing businesses, attracting new businesses and finding export markets.

Leigh and Blakely (2013) state that LED has as its ultimate goal the economic development of a demarcated local area; it is a process by which local government and local communities manage existing resources and en sure parterships with the private sector to create new jobs and stimulate local economic activities. Van Zyl (1994) explains the process of the economic development of a region as the overall improvement of the quality of life of allocal residents, the alleviation of poverty and a change in the structure of the community regarding economics and social aspects. He explains that this should result in improved levels of productivity and income and also lead to the modernisation of the local economy. Helmsing and Egziabher (2005), as well as Swinburn (2006), make the point that LED is a process which facilitates cooperation between local government, local communities and local business, leading to better utilisation of local resources. This process should result in an increase in economic activities. Pretorius and Schurink (2007) state that LED may assist local government to improve its governance, due to the fact that improved governance could lead to enhanced institutional capacity, management and administration. They state that it is the ability to co-ordinate and assist with implementation of policies, projects and action plans. Governance also includes public involvement, institutional development, transparency in the decision-making process and accountability. Good governance underpins LED, and the main link between the two concepts is that they provide a local business enabling environment (Trousdale, 2005).

The process of LED may lead to success, if well implemented. According to Trousdale (2005), factors may include effective leadership; the creation of a developmental and enablingenvironment that supports economic development; the involvement of the community and especiallyyouths in development initaitives; jobcreation initiatives for poverty reduction;skills development within all sectors of the local economy and lastly, the improvementinqualityof life.Partnerships between local role players are essential for LED success. The objectives of such partnerships are to improve the flow and exchange of information, to enhance the local enabling environment, promote local business opportunities and facilitate joint activities between partners (Srinivas, 2015). Existing groups in a specific region such as business chambers play an essential role in sustainable partnerships. Local government has the following roles to play in the partnership development process; the development of policy and strategies; provision of infrastructure and incentives as well as research, training and business support (Srinivas, 2015). According to Leigh and Blakely (2013) and supported by VNG International (2007), local government and local businesses perform the following main economic development roles and functions: 
Facilitator: This function involves the delivery of processes and facilities and attraction of investment through effective policy formulation regarding the creation of an enabling economic environment.

Co-ordinator: The LED process forms a key programme for co-ordination with local communities. Business networks through business partners and chambers need to be established.

Enabler: Furnish expert advice, assistance and support, information, training, business planning.

Stimulator: The stimulation of local businesses to expand and attract new business investment in the region. The relevant tools to achieve this could include business incubation, the offering of development incentives, provision of grants and tourism development.

Developer: Provision of basic infrastructure to encourage private sector development such as electricity, water, roads, and sewers.

The national strategic planning document, the National Development Plan (NDP), states that the role of government is to coordinate the economic development by removing barriers, such as service capacity problems, lack of infrastructure development and skills training. Development occurs in the local sphere, and one of the aims of the NDP is to improve the capacity of local government (The Presidency, 2012). According to the Department of Cooperative Governance (2014), local government needs to play a major role in local development through leadership, policy guidelines, the creation of an enabling environment and development of small business. For local government, some challenges in establishing an enabling environment include the skewed spatial development, high levels of inequality, unstable financial systems and a lack of qualified and experienced staff (South Africa, 1998; South Africa, 2014). In research previously undertaken, Meyer (2014) identified different factors for local government to create an enabling developmental environment, such as:

Partnership formation: Local government must ensure strong and high-quality public participation (Mathekga \& Buccus, 2008). The development of comparative advantages could be enhanced using partnerships between the public and private sector (Koven \& Lyons, 2003; Davis, 2004; Human, Lochner \& Botes, 2008). Better relations are associated with faster growth and ease of regulations (UNIDO, 2008).

Local government structures, capacity, policies and initiatives: Effective integrative policies and also institutional capacity are a prerequisite for good governance, which includes a compact and streamlined institution (Trousdale, 2005; Hindson \& Meyer-Stamer, 2007; Human et al., 2008; CIDA, 2009; WEF, 2011). In order to achieve integrated economic development and to reduce poverty, good governance and political stability are required (Abdula, 2008; Konig et al., 2013).

Local leadership: Local economic development requires stable policies and leadership. Local leadership from government, business, and local communities areneeded, and these stakeholders should collaborate as local champions that drive economic development (Swinburn et al., 2006; Todaro \& Smith, 2011).

Poverty alleviation and social development initiatives: Economic development is not simply about economic development per se, but social-welfare components are also of importance with the aim of improving the quality of life. In this regard, the focus should be placed on social aspects, such the provision of basic needs and community facilities. These needs include water, shelter, nutrition, healthcare, sanitation, education, skills, the ability to find work, a sense of belonging and well-being as well as access to land (Sachs, 2005; NRI, 2006; Todaro \& Smith, 2011; The Presidency 2012).

Local economic development initiatives (LED): The goals of LED are to create jobs and to improve the quality of life of local communities. Employment will ensure an improved quality of life and an increase in per capita income. The development of entrepreneurship and small business are an important part of any LED strategy. Exports and value-added production are also vitally important (Davis, 2004; Leigh \& Blakely, 2013).

Environmental and spatial development actions: Clean, quality physical environments attract economic development where sound environmental management is practised (Muslow, 2001; Koven \& Lyons, 2003; CIDA, 2009; The Presidency, 2012). Spatial planning is based on the strategic planning process and gives direction in local economic planning (Meyer, 2013). 
Infrastructure development: A stumbling block to economic development is any lack of basic infrastructure as well as inadequate capacity in maintaining it (Leigh \& Blakely, 2013; CIDA, 2009). Investment in new 'hard' and 'soft' infrastructure is a requirement for an enabling developmental environment (DPLG, 2001; Amis, 2002; Trousdale, 2005). The provision of effective infrastructure includes well designed and maintained roads, water, sewers, ports, storage and energy generation (Davis, 2004; Koniget al., 2013).

Human resource development: An unskilled labour force with limited entrepreneurial intent is a barrier to economic development. (CIDA, 2009). The current strict labour regulations in South Africa exert an adverse impact on job creation and development (UNIDO, 2008).

Entrepreneurship development: Entrepreneurship development is an important aspect of improving economic growth and is considered imperative for solving challenges relatedto unemployment, poverty and other social issues (Meyer \& Mostert, 2016). Strong entrepreneurial intent and the development thereof is a requirement for a competitive economy (UNIDO, 2008). Aspects such as high marginal tax rates and legislative regulation pose barriers to entrepreneurs and small business development (Meyer-Stamer, 2003).

Transport and access opportunities: South Africa, with its history of separate race-based development, has caused the majority of its population to be isolated from economic activities so that access to economic opportunities is vital (Sibisi, 2009).

Agricultural development: Agriculture is a major sector regarding job creation, alleviation of poverty, food security and a positive trade balance (Aliber, 2003).

Safety and security: A secure environment is essential for economic development. High levels of crime and poor safety and security are usually associated with low levels of economic development (Goulas \& Zervoyianni, 2012).

\section{Methodology}

The main focus of this article is the testing of the reliability and validity of the research instrument. The validity of the instrument signifies that the measurement tool measures what it claims to, while its reliability indicates how consistent the result will be if it is used again in similar situations (Cresswell, 2013). The construct validity of a questionnaire was tested by using factor analysis. Construct validity refers to how well the items in the questionnaire signify the underlying theoretical structure. One of the techniques to test for constructs or domains within the development of a measurement is factor analysis (Rattray \& Jones, 2007).

Early Development Stage of the Enabling Developmental Environment Scale: As mentioned by Rattray and Jones (2007) questionnaire development and the research design need to follow a logical, systematic and structured approach. When a questionnaire is not sufficiently developed, it may lead to difficulty in interpreting the result. Furthermore, it is important to ensure that sufficient pilot work is carried out during the devising of any new questionnaire or measurement instrument. In this research, the questionnaire items were initially developed according to the research objectives and findings from the relevant literature regarding an enabling environment. The questionnaire consisted of two parts. Part one of the questionnaire composed of 11 biographical questions. Part Two of the questionnaire initially consisted of 13 items, but through discussion with researchers and professionals in the area, it was reduced to 12 items. The 12 item scale was rated on a five-point Likert Scale. The participants were required to indicate $0=$ very poor to $5=$ very good. Within the LED research field, the Likert-type scales or frequency scales are commonly used in research as these questions are fixed choice responses.

The Sample and testing: The Sample and testing: Formal and informal business owners were invited to participate in this study within the Vaal Triangle area, South Africa. The sample size was determined by following the guidelines developed by Field (2013), to choose 10 to 15 participants per item (total of 120-144 participants) to allow for evaluation of content validity through factor analysis of items. The sample size in this article was guided by Nunnally (1978) to include at least 10 participants per item (i.e., > 120 
participants) to ensure construct validity through factor analysis of the items. A total of 152 participants (formal sector owners $=93$ and informal sector owners $=57$ ) returned the questionnaire. All 152 cases were included in the factor analysis as there were no missing values for single items.

Statistical method: Data were analysed by using IBM SPSS version 23 with descriptive statistics for single variables. During the first phase of the data analysis, the construct validity of the Enabling Developmental Environment Scale (EDES) was assessed. Before performing principal factor extraction, principal component extraction was carried out to determine the estimated number of factors, the presence of outliers and the factorability of the matrices. The Eigen values and screen plots were studied to determine the number of factors involved. A principal axis factor analysis with a direct oblimin rotation was conducted to extract the factors (Tabachnick \& Fidell, 2001). With the second phase of the data analysis, the reliability of the 12 items was carried out byutilising Alpha reliability. According to Nunnally (1967), the Cronbach's Alpha coefficient values need to be above 0.60 to be acceptable. Furthermore, the said coefficient also provides information regarding which of the items of the instrument are related to each other and whether any items need to change or be removed from the scale (Pallant, 2007).

Ethical considerations: Each questionnaire included a covering letter, which clearly stated that participation in this study was voluntary. The purpose of the research was also explained. Confidentiality and anonymity were guaranteed. The participants' informed consent was given by completing and returning the questionnaire to the trained fieldworkers.

\section{Results}

Descriptive statistics: Table 1 is a summary of the descriptive statistics obtained from the surveys. The majority of participants included in this study were from the formal business sector; that is $61.2 \%$, while $37.2 \%$ came from the informal sector. A total of $42.8 \%$ of the businesses were classified as large firms while $30.9 \%$ were classified as small and micro-sized businesses. The business environment seemed stable, with a total of $34.9 \%$ of these businesses having existed for longer than ten years.

\section{Table 1: Characteristics of participants}

\begin{tabular}{|c|c|c|c|}
\hline Item & Category & Frequency & Percentage \\
\hline \multirow[t]{4}{*}{ Business type } & Formal & 93 & 61.2 \\
\hline & Informal & 57 & 37.2 \\
\hline & Missing value & 2 & 1.3 \\
\hline & Total & 152 & 100 \\
\hline \multirow[t]{6}{*}{ Business size } & Large (more than 200 employees) & 65 & 42.8 \\
\hline & $\begin{array}{l}\text { Medium (more than } 50 \text { but less than } 200 \\
\text { employees) }\end{array}$ & 38 & 25.0 \\
\hline & $\begin{array}{l}\text { Small (more than ten but less than } 50 \\
\text { employees) }\end{array}$ & 22 & 14.5 \\
\hline & Very Small/Micro (less than ten employees) & 25 & 16.4 \\
\hline & Missing values & 2 & 1.3 \\
\hline & Total & 152 & 100 \\
\hline \multirow[t]{9}{*}{ Time in existence } & $0-6$ months & 1 & 0.7 \\
\hline & Six months but less than 12 months & 3 & 2.0 \\
\hline & One year but less than two years & 7 & 4.6 \\
\hline & Two years but less than three years & 28 & 18.4 \\
\hline & Three years but less than five years & 23 & 15.1 \\
\hline & Five years but less than ten years & 36 & 23.7 \\
\hline & Longer than ten years & 53 & 34.9 \\
\hline & Missing values & 1 & 0.7 \\
\hline & Total: & 152 & 100 \\
\hline
\end{tabular}


Construct validity: Table 2 is a summary of the results of the survey of the 152 businesses and their perceptions regarding the current enabling environment. A 5 point Likert scale was used with a score of 1 indicating very limited compliance regarding the specific factor, while a score of 5 indicated excellent compliance regarding the specific factor. The overall average score allocated by all business for all 12 factors included in the scale was 1.3. This result indicates low overall compliance in the creation and establishment of an enabling environment for business to prosper. The factors that scored the lowest were leadership (0.9) and safety and security (0.9). The factors that scored the highest, indicating highest levels of compliance were economic development initiatives (1.7), structures and policies (1.5), infrastructure (1.5) and entrepreneurship development (1.5). In an overall assessment of the results, it is evident that local government in the study region is not providing an adequate level of an enabling environment for business development. None of the factors had an indication of acceptableprovision and all 12 factors needs to be address for businesses to be successful in the region. Strong and effective leadership and the lack of safety and security are the two areas where most attention is needed, although all factors need improvement.

Table 2: Descriptive statistics - means, Standard Deviation, Range, Skewness, Kurtosis, kurtosis

\begin{tabular}{|c|c|c|c|c|c|c|c|}
\hline & $\begin{array}{l}\mathbf{N} \\
\text { Statistic }\end{array}$ & $\begin{array}{l}\text { Mean } \\
\text { Statistic }\end{array}$ & Statistic & $\begin{array}{l}\text { Std. } \\
\text { Deviation } \\
\text { Statistic }\end{array}$ & $\begin{array}{l}\text { Skewness } \\
\text { Std. Error }\end{array}$ & $\begin{array}{l}\text { Kurtosis } \\
\text { Statistic }\end{array}$ & Std. Error \\
\hline Partnership formation & 148 & 1.277 & 1.0931 & 0.443 & 0.199 & -0.857 & 0.396 \\
\hline Structures and policies & 149 & 1.477 & 1.3131 & 0.605 & 0.199 & -0.685 & 0.395 \\
\hline Leadership & 150 & 0.987 & 0.8898 & 1.301 & 0.198 & 2.345 & 0.394 \\
\hline $\begin{array}{l}\text { Poverty alleviation an } \\
\text { social development }\end{array}$ & d 150 & 1.280 & 1.3567 & 2.861 & 0.198 & 16.689 & 0.394 \\
\hline $\begin{array}{l}\text { Economic developmen } \\
\text { initiatives }\end{array}$ & nt150 & 1.747 & 1.4891 & 0.308 & 0.198 & -1.231 & 0.394 \\
\hline $\begin{array}{l}\text { Environmental } \\
\text { spatial plans }\end{array}$ & $\mathrm{d} 150$ & 1.240 & 1.1854 & 1.042 & 0.198 & 0.577 & 0.394 \\
\hline infrastructure plans & 150 & 1.533 & 1.4640 & 2.125 & 0.198 & 10.492 & 0.394 \\
\hline HR development & 150 & 1.213 & 1.3189 & 3.210 & 0.198 & 19.670 & 0.394 \\
\hline $\begin{array}{l}\text { Entrepreneurship } \\
\text { development }\end{array}$ & 150 & 1.547 & 1.3639 & 0.448 & 0.198 & -1.029 & 0.394 \\
\hline $\begin{array}{l}\text { Improvement of acces } \\
\text { and transport }\end{array}$ & $s 150$ & 1.193 & 1.1034 & 0.885 & 0.198 & 0.385 & 0.394 \\
\hline Agriculture development & 150 & 1.107 & 1.2961 & 3.530 & 0.198 & 22.386 & 0.394 \\
\hline Safety and security & 150 & 0.987 & 0.8822 & 1.334 & 0.198 & 3.064 & 0.394 \\
\hline
\end{tabular}

Figure 1: Screen plot of the EDES

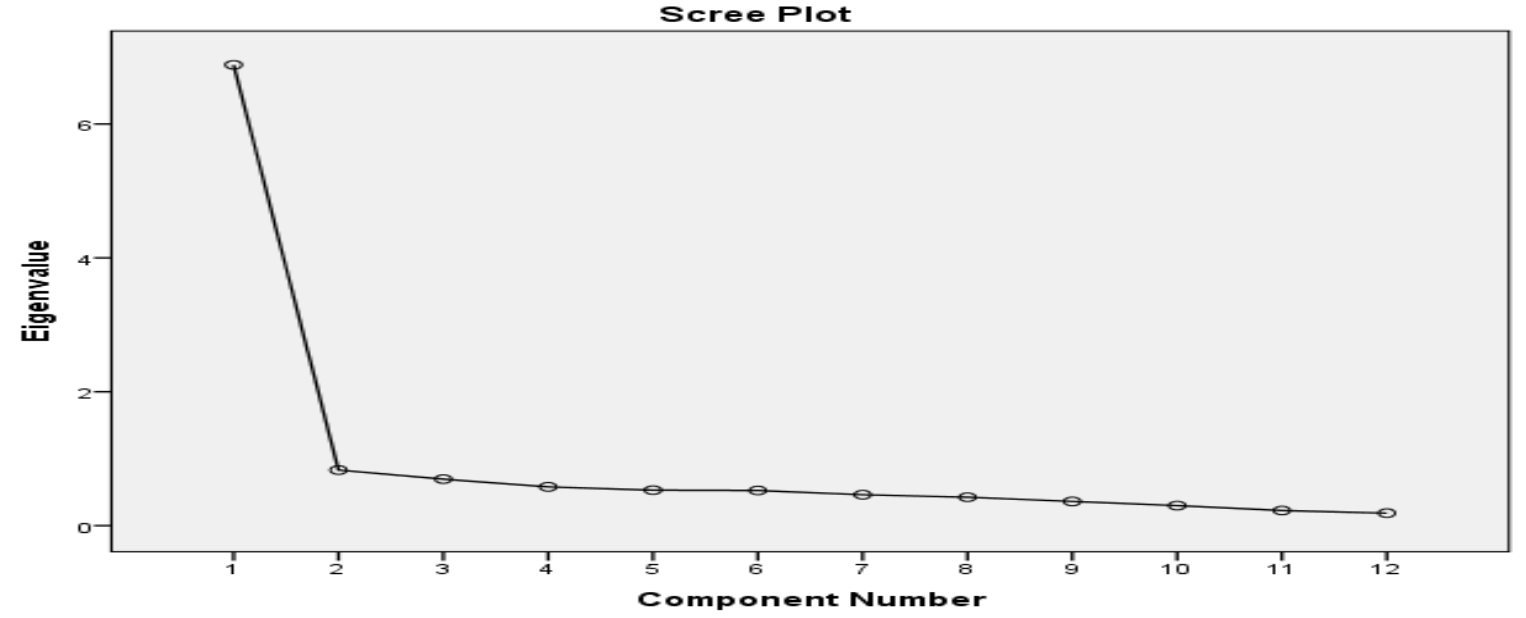


Table 3: Factor Loadings, Communalities $\left(\mathrm{h}^{2}\right)$ and Percentage Variance for Principal Axis Factor Analysis on Enabling Environment Scale Items

\begin{tabular}{llll}
\hline Item & Description & $\mathbf{F}_{\mathbf{1}}$ & $\boldsymbol{h}^{\mathbf{2}}$ \\
\hline 1. & Partnership formation & 0.825 & 0.680 \\
2. & Structures and policies & 0.777 & 0.603 \\
3. & Leadership & 0.775 & 0.601 \\
4. & Poverty alleviation and social development & 0.651 & 0.423 \\
5. & Economic development initiatives & 0.865 & 0.748 \\
6. & Environmental and spatial plans & 0.751 & 0.564 \\
7. & Infrastructure plans & 0.753 & 0.567 \\
8. & HR development & 0.733 & 0.538 \\
9. & Entrepreneurship development & 0.818 & 0.669 \\
10. & Improvement of access and transport & 0.796 & 0.633 \\
11. & Agriculture development & 0.620 & 0.384 \\
12. & Safety and security & 0.688 & 0.473 \\
Percentage variance & 57.359 & \\
\hline
\end{tabular}

Extraction Method: Principal Component Analysis.

a. 1 components extracted

Reliability of measurement instrument: The reliability analysis demonstrated that the instrument was substantially reliable. The 12 items indicated that the Cronbach Alpha Coefficient was 0.928; Table 3lists the internal consistency of the scale per item.

Table 4: Test of internal consistency of scale and items were performed using the Cronbach Alpha coefficient

\begin{tabular}{llllc}
\hline Item & $\begin{array}{c}\text { Scale Mean if } \\
\text { Item Deleted }\end{array}$ & $\begin{array}{c}\text { Scale Variance if } \\
\text { Item Deleted }\end{array}$ & $\begin{array}{c}\text { Corrected } \\
\text { Item-Total } \\
\text { Correlation }\end{array}$ & $\begin{array}{c}\text { Cronbach's } \\
\text { Alpha if Item } \\
\text { Deleted }\end{array}$ \\
\hline Partnership formation & 14.216 & 99.504 & 0.776 & 0.919 \\
Structures and policies & 14.014 & 97.075 & 0.725 & 0.921 \\
Leadership & 14.507 & 103.639 & 0.722 & 0.922 \\
Poverty alleviation and social development & 14.209 & 99.677 & 0.589 & 0.927 \\
Economic development initiatives & 13.736 & 91.610 & 0.829 & 0.916 \\
Environmental and spatial plans & 14.250 & 99.549 & 0.699 & 0.922 \\
Infrastructure plans & 14.020 & 98.727 & 0.699 & 0.922 \\
Human resource development & 14.345 & 102.132 & 0.676 & 0.923 \\
Entrepreneurship development & 13.939 & 95.064 & 0.773 & 0.919 \\
Improvement of access and transport & 14.297 & 99.857 & 0.744 & 0.920 \\
Agriculture development & 14.385 & 101.408 & 0.552 & 0.928 \\
Safety and security & 14.507 & 105.408 & 0.626 & 0.925 \\
\hline
\end{tabular}

Furthermore, the results of running the procedure as explained for this scale validation indicate that if items were deleted in SPSS for all the items, this did not alter the overall reliability estimate significantly as these entire alpha scores remained above 0.90 . Item-total correlations were performed to assess the internal consistency. To ensure that bias was reduced a corrected item-total correlation was calculated. The latter varied between 0.552 and 0.829 .

Discussion: This study indicates that researchers need to follow a logical, systematic and structured approach to developing a questionnaire as suggested by Rattray and Jones (2007). Therefore, it is important that each step in developinga questionnaireneed to be systematically planned. As indicated above, the researchers have first defined the construct and then determined the content by doing an extensive literature review. After the said extensive review, the researchers started with the generation of each item. In this 
research, it was decided to utilise closed-ended questions with a 5-point Likert Scale. After the items had been developed, the researchers used a group of specialist and professionals in the area to evaluate the items. They suggested that the original 13 -item scale is reduced to 12 items. To pilot test the instrument, the current sample size of 10 respondents per item as recommended by Nunnally (1978) was followed. Reliability analysis and validity analysis of the EDES demonstrated adequate internal consistency and validity of the scale; therefore the level of reliability and validity is acceptable. The EDES could serve as a standard regarding the measurement of the enabling environment levels of economic development. Based on the results of the EDES, it could be regarded as a suitable instrument for measuring levels of the enabling environment for economic development.

The study encountered a few limitations. The newly developed scale relied upon a self-reported measurement, and it should be acknowledged that self-reported questionnaires have constraints. As explained by Razavi (2001, p. 17), "Traditional criticisms of self-report methodologies, especially response biases, must, therefore, be taken into account in the construction of questionnaires, and the analysis and interpretation of data derived from them, but with express reference to the purpose of the study and the nature of the construct of interests." A cross-sectional design was followed; however, if this questionnaire were used in a longitudinal study, it could create a better understanding of the enabling development in LED. More work is needed to determine the validity and reliability of the scale in different regions in South Africa and other developing regions in the world. It is also suggested that larger sample sizes need to be used to provide increased confidence that the study findings could be applied consistently across similar groups.

\section{Conclusion and Recommendations}

Regarding the findings regarding the Enabling Developmental Environment Scale (EDES) obtained from this study, the use of the scale was proved to be valid and reliable. It is recommended that future studies should include larger samples and utilise a more powerful sampling method that could be used to enable generalisation to similar groups. Techniques such as structural equation modelling and equivalence analysis could also be employed for future studies. In conclusion, it is important to note that the scale could be used to assess regions and local areas and could also be utilised to compare different regions. It is also possible, through the use of the scale, to monitor progress and to formulate strategies to improve the enabling environment.

List of Abbreviations: CIDA - Canadian International Development Agency; DPLG - Department of Provincial and Local Government; EDES - Enabling Developmental Environment Scale; ETU - Education and Training Unit; LED - Local Economic Development; NDP - National Development Plan; NRI - Natural Resources Institute; REED - Rural Economic and Enterprise Development; SALGA - South Africa Local Government Association; UNIDO -United Nations Industrial Development Organization; WEF - World Economic Forum

\section{References}

Abdula, D. (2008). Enabling Environments for Agri-business and Agro-industry Development in Africa. Proceedings of an FAO Workshop. Rome.

Aliber, M. (2003). Chronic Poverty in South Africa: Incidence, Causes and Policies. World Development, 31(3), 473-490.

Amis, P. (2002). Municipal Government, Urban Economic-Growth and Poverty Reduction: Identifying the Transmission Mechanisms between Growth and Poverty. In C. Rakadi and T. Lloyd-Jones. (Eds.). Urban Livelihoods: A People-Centered Approach to Reducing Poverty. London: Earth Scan. p. 112-133.

Canadian International Development Agency (CIDA). (2009). Stimulating Sustainable Economic Growth. Toronto, Canada.

Christy, R., Mabaya, E., Wilson, N., Mutambatsere, E. \& Mhlanga, N. (2009). Enabling Environments for Competitive Agro-Industries. Wallingford, UK.: CABI.

Cohen, D. (2010). SALGA LED Position Paper: Key Issues in Local Economic Development in South Africa and A Potential Role $\quad$ For SALGA. Retrieved from 
http://www.salga.org.za/app/webroot/assets/files/PositionPapers/SALGA\%20Position\%20Pap er\%20on\%20Local\%20Economic\%20Development.pdf.

Creswell, J. W. (2013). Qualitative inquiry and research design: Choosing among five approaches. Thousand Oaks, CA: Sage.

Davis, J. (2004). Using the Rural Economic and Enterprise Development (REED) Framework for Analysis and Joint Action: Implications for Spatial Development. Natural Resources Institute (NRI). May 2004. Retrieved fromhttp://www.nri.org.

Department of Cooperative Governance. (2014). Draft National Framework for Local Economic Development, 2014-2019. Pretoria: Government Printer.

Department of Provincial and Local Government (DPLG). (2001). Toolkit for LED. Pretoria: Government Printer.

Education and Training Unit (ETU). (2012). Understanding Local Government. Retrieved from http://www.etu.org.za.

Field, A. (2013). Discovering Statistics using IBM SPSS Statistics (4th ed.), New Delhi: Sage.

Goulas, E. \& Zervoyianni, A. (2012). Economic Growth and Crime: Does Uncertainty Matter? The Rimini Centre for Economic Analysis, Working Paper No. 51, Rimini.

Helmsing, A. H. J. \& Egziabher, T. G. (2005). Local Economic Development in Africa: Introducing the Issues. In T.G. Egziabher, \& A. H. J. Helmsing, (Eds.). Local Economic Development in Africa: Enterprises, Communities and Local Development. Maastricht. Shaker Publishing BV.

Hindson, D. \& Meyer-Stamer, J. (2007). The Local Business Environment and Local Economic Development: Comparing Approaches. Mesopartner, Working Paper 11/2007. Duisberg, Germany.

Humby, T. (2015). Local economic development and the pursuit of a green economy. In A. Du Plessis (ed). Environmental Law and Local Government in South Africa. Cape Town: Juta.

Human, F., Lochner, M. \& Botes, L. (2008). Marketing Plans Against All Odds: LED in Small Towns of the Free State Province, South Africa. Africa Insight, 38(1), 53-66.

Konig, G., Da Silva, C. A. \& Mhlanga, N. (2013). Enabling Environments for Agri-business and Agro-industries Development. Rome: Food and Agriculture Organization of the United Nations.

Koven, S. G. \& Lyons, T. S. (2003). Economic Development: Strategies for State and Local Practice.Washington, DC: ICMS.

Leigh, N. G. \& Blakely, E. J. (2013). Planning Local Economic Development: Theory and Practice. (5 ${ }^{\text {th }}$ edition). California: Sage Publications.

Mathekga, R. \& Buccus, I. (2008). The Challenge of Local Government Structures in South Africa: Securing Community Participation. Durban: Centre for Public Participation.

Meyer, D. F. (2014). Local Government's Role in the Creation of an Enabling Developmental Environment. Administration Publica, 22(1), 24-46.

Meyer, D. F. (2013). An Exploration of Solutions for Rural Development: The Case of the Northern Free State. (PhD thesis), Vanderbijl park, South Africa: North West University Vaal Campus.

Meyer, N. \& Mostert, C. (2016). Perceived Barriers and Success Factors of Female Entrepreneurs Enrolled in an Entrepreneurial Programme. International Journal of Social Sciences and Humanity Studies, 8(1), 48-66.

Meyer-Stamer, J. (2003). Stimulating Rural Enterprise in South Africa: Lessons from LED. Paper presented at Conference on 21-23 May 2003. Retrieved from www.mesopartner.com.

Mountford, D. (2009). Organising for Local Development: The Role of Local Development Agencies. Summary Report, 26-27 November 2009, working document, CFE/LEED, OECD. Retrieved fromwww.oecd.org/dataoecd/54/41/44682618.pdf?contentId=446.

Muslow, B. (2001). Making Development Sustainable. In J.K. Coetzee, J. Graaff, F. Hendricks, and G. Wood. (Eds.). Development: Theory, Policy and Practice. New York: Oxford University Press.

National Resources Institute (NRI). (2006). Addressing Poverty Through Local Economic and Territorial Development. Retrieved from http://www.nri.org.

Nel, E. \& Rogerson, C. M. (2005). Pro-Poor Local Economic Development in South Africa Cities: Policy and Practice. Africa Insight, 35(2), 5-20.

Nunnally, J. C. (1967). Psychometric Theory. New York: McGraw-Hill.

Nunnally, J. C. (1978). Psychometric Theory. New York: McGraw-Hill. 
Pallant, J. (2007). SPSS Survival Manual: A Step by Step Guide to Data Analysis Using SPSS for Windows (3rd ed.). Maidenhead, UK II: Open University Press.

Pretorius, D. \& Schurink, W. (2007). Enhancing Service Delivery in L ocal Government: The Case of a District Municipality. SA Journal of Human Resource Management, 5(3), 19-29.

Rattray, J. C. \& Jones, M. C. (2007). Essential Elements of Questionnaire Design and Development. Journal of Clinical Nursing, 16, 234-243.

Razavi, T. (2001). Self-Report Measures: An Overview of Concerns and Limitations of Questionnaire Use in Occupational Stress Research. Southampton, UK: University of Southampton,23pp. (Discussion Papers in Accounting and Management Science, 01-175).

Sachs, J. (2005). End of Poverty: Economic Possibilities For Our Time. New York: Penguin.

Sibisi, S. (2009). Brushing Against the Grains of History: Making Local Economic Development Work in South Africa. Midrand: Development Planning Division, Working Paper Series no 5. DBSA, March 2010.

South Africa Republic. (1996). Constitution of the Republic of South Africa (Act 108 of 1996) as Adopted by the Constitutional Assembly on 8 May 1996. Pretoria: Government Printer.

South Africa Republic. (1998). White Paper on Local Government. Constitutional Development. Pretoria: Government Printer.

South Africa Republic. (2014). Public Administration Management Act (Act 11 of 2014). Pretoria: Government Printer.

Srinivas, H. (2015). The Role of Local Governments in Fostering Business Partnerships for Environmental Sustainability. Kobe, Japan: GDRC Research Output E-076.

Swinburn, G. (2006). Local Economic Development: Quick Reference. Washington, World Bank.

Swinburn, G., Goga, S. \& Murphy, F. (2006). Local Economic Development: A Primer for Developing and Implementing Local Economic Development Strategies and Action Plans. Washington DC: The World Bank.

Tabachnick, B. G. \& Fidell, L. S. (2001). Using Multivariate Statistics ( $4^{\text {th }}$ ed.). Boston: Allyn and Bacon.

The Presidency. (2012). National Development Plan (NDP) - 2030. The National Planning Commission. Pretoria: Government Printer.

Todaro, M. P. \& Smith, S. C. (2011). Economic Development, (11 ${ }^{\text {th }}$ ed.). Essex: Pearson Education.

Travers, T. (2012). Local Government's Role in Promoting Economic Growth. London: Local Government Association.

Trousdale, W. (2005). Promoting Local Economic Development Through Strategic Planning. The Local Economic Development Series, 1 to 5. Nairobi, UN-Habitat.

United Nations Industrial Development Organization (UNIDO). (2008). Creating an Enabling Environment for Private Sector Development in Sub-Saharan Africa. Vienna, Austria.

Van den Dool, L. (2005). Making Local Government Work. Delft: Eburon.

Van Zyl, J. (1994). Development Management: A Training Perspective. Midrand: DBSA.

VNG International. (2007). The Role of Local Government in Local Economic Development. The Hague, The Netherlands: VNG International.

World Economic Forum (WEF). (2011). The Future of Government: Lessons Learned from Around the World. Cologny. Switzerland. Retrieved from www.weforum.org. 